\title{
PERCEIVED QUALITY OF RURAL TOURISM ACCOMMODATION SERVICES BY PROSPECTIVE CUSTOMERS
}

\author{
Iveta Dembovska \\ Inese Silicka \\ Lienite Litavniece \\ Rezekne Academy of Technologies
}

\begin{abstract}
Rural tourism and corresponding activities generate new jobs, providing employment for people in rural areas, create a cooperation mechanism between different rural entrepreneurs, attract tourists, and thus contribute to both well-being of local population and the regional development in general. Rural tourism is attractive from an economic perspective, as it provides the opportunity to boost and diversify rural economies in remote areas. The paper is a part of the RTA scientific grant "Tourism Products Evaluation of the Rezekne Municipality (Quality Audit)". The aim of the research is to study rural tourism accommodation services in Rezekne municipality and to carry out their evaluation based on experts' (potential customers') perception of quality. The methods applied in the research: logical and constructive, synthesis and analysis, an empirical survey. However, the rural tourism accommodation establishments in Rezekne municipality in general are characterized by the keywords "responsiveness" and "hospitality" as well as by the well-ordered environment around the houses. The rural housings have to evaluate the current and future demand and precisely define the potential market segments to create an offer in accordance with it.
\end{abstract}

Keywords: accommodation services, local economy, quality, rural tourism, satisfaction, tourism.

\section{Introduction}

Tourism is a rapidly growing sector of the Latvian economy. The successful development of the sector is determined by both the natural resources, geographically advantageous location, rich historical and cultural heritage, and the talents of the Latvian people, growth-oriented work, and hospitality (Latvian Investment and Development Agency).

In the global tourism economy, the rural tourism is defined as an economic activity where the profits are gained by use of agricultural land, natural resources, cultural heritage, agricultural holdings, local traditions and products, appropriately labelling them, reflecting regional identity, and serving the needs of tourists (overnight stays, entertainment, and other services) in order to promote 
sustainable local development and to meet the demands of modern society for proper service in the context of new social solidarity between rural and urban areas (Naktsmītnes lauku un regiionālajā tūrismā).

Rural tourism and the related activities generate new jobs providing people in rural areas with employment, create a mechanism for cooperation between different rural entrepreneurs, attract tourists, and thus contribute to both increase of the well-being of local people, and the regional development in general. However, these impacts cannot occur when there is no more population in the area that can be employed in rural tourism or in other related sectors.

Moreover, tourism is considered an incentive for economic development in remote areas, in the regions experiencing stagnation or decline in the primary economic sector, but lacking the capacity to absorb large-scale industrialization or other alternatives. Sustainable tourism serves as a driving force to stimulate economic growth in developing areas and to reduce the subsequent decline. Rural tourism is attractive from the economic point of view, as it has the opportunity to replenish and diversify rural economies in remote areas. It is also claimed that it has access to social and cultural benefits as a platform for advocacy of interests. Tourism growth and the economic development of the tourism industry in Latvia are often evaluated mainly in relation with two economic indicators - changes in the number of foreign travellers, and the amount of money spent by travellers (Dembovska \& Silicka, 2014).

Local governments also have a significant role in rural tourism - tourism development in their own territory provides a good opportunity to supplement the municipal budget, thus having additional funds to promote small business development, growth of cultural institutions, as well as opportunity to improve road infrastructure, raise the level of catering establishments, and develop trade, crafts. Particularly for the local municipalities, tourism potential (natural and historical sites) can turn into tourism resources by including them on tourist routes and excursions, offering to spend entertaining time in nature for tourists. Particularly with the support of the local authorities, hotels and catering establishments are being built and arranged, travel packages are being developed that can be realized in a particular area.

The aim of the research is to study rural tourism accommodation services in Rezekne municipality and to carry out their evaluation based on experts' (potential customers') perception of quality. Tasks to achieve the goal:

- theoretical sources on opinions of "perceived quality" are explored;

- the results of the expert-client ("hidden guest") survey are summarized and analysed.

The methods applied in the research: logical and constructive, synthesis and analysis, an empirical survey. 


\section{Research and discussion}

The term "rural tourism" is often used when rural culture is the main component of the product offered. The main feature that helps to distinguish the offer of the rural tourism product is a desire to provide the traveller with a personalized contact, opportunity to enjoy the rural physical environment and get to know people, and to allow participate in the daily activities of local people observing their traditions and lifestyle whenever possible (Naktsmìtnes lauku un reǵionālajā tūrismā).

Quality of rural tourism should be considered as a factor contributing to entrepreneurship and product and destination development. The quality of the tourist accommodation hence the quality of the customer's safety, convenience, catering, additional services, etc. is related to the implementation of the rules and regulations that are determined by the national and international standards. The potential risk factors in the premises of the building and its surroundings determine the customer's safety and guarantee the reliability of quality: a location of the premises, its space and convenience; technical condition and quality of buildings and premises; technical condition and quality of furniture and equipment; water supply and its quality; sanitary norms; technical equipment, etc. (Daugeliene, 2006).

The assessment of the "perceived quality" of rural tourism services depends on the selection of the correct factors (elements) affecting the customer's satisfaction. The selection of these factors determines appropriate management decision making and rural business accommodation improvement processes in order to meet the needs of visitors as fully as possible. An important factor for successful development is support of the stakeholders/interested parties resulting in the quantitative demand for rural tourism accommodation. Both the definition of a rural tourism accommodation establishment, an understanding of quality of the modern rural tourism accommodation services, and tourism sustainability approaches emphasise the interests of stakeholders that are the basis of all activities in the tourism enterprise. Thus, the authors conclude that organization of quality management for rural tourism accommodation establishments has a great influence on its sustainable development (Figure 1).

Based on Figure 1, it is possible to conclude that, on the one hand, satisfaction with rural tourism accommodation services is influenced by supply, but on the other hand - by demand, that is based on the customer's character, perception, experience, values, and reasons of choosing a particular service. 


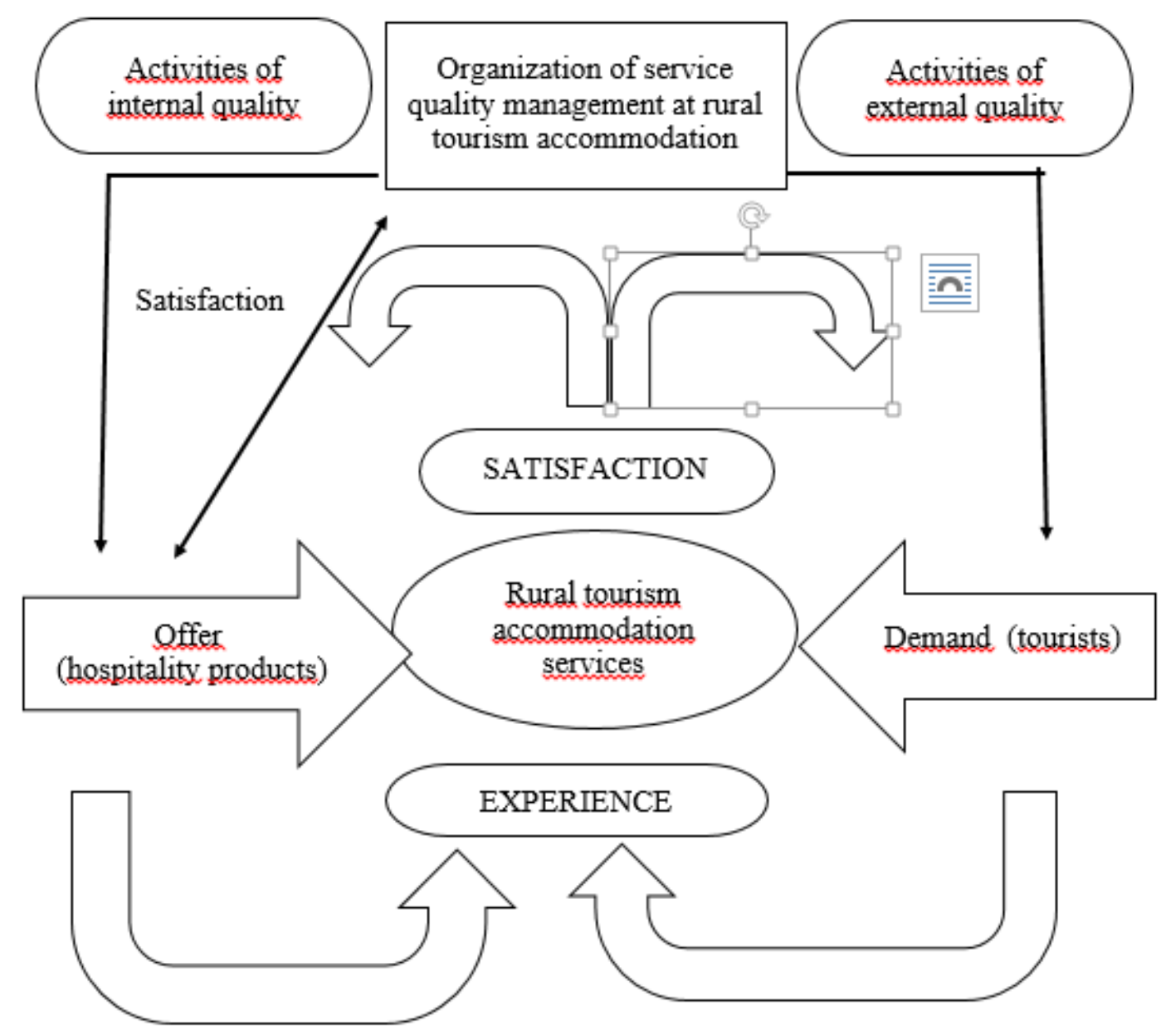

Figure 1. Activities in the organization of quality management and their impact on the long-term development of tourism establishments (Steina, 2012)

Noriaki Kano (Kano, 1996) is one of the scientists who has researched the "perceived quality" and distinguished 3 categories of factors that influence the way the customer perceives an offered service. He specifies that particular elements of a service may cause positive and negative reaction of the customer. The customer's satisfaction (i.e. a conscious consumer's value) increases with the improvement of a particular quantitative or qualitative factor.

Must-be (critical) service factors - are the main factors that influence the customer and the essence of the offered service directly. Unexpected (attraction) factors may cause positive reaction if the customer's expectations of rural tourism accommodation services are exceeded. Neutral or indifferent categories (factors that influence the consumer's satisfaction) factors, which do not influence the customer reaction. „Reverse” categories (factors influencing the consumer's satisfaction) stand for the existence or non-existence of a particular service quality which may equally cause satisfaction to part of the customers, as well as 
indifference or even dissatisfaction among other guests (Dembovska, Litavniece, \& Silicka, 2017).

Using the factors named by N. Kano, it is possible to determine an action's influence on the service consumer's value in rural tourism accommodation services; to find out immediately which must-be qualities have to be included in the service; which qualities may serve as a "zing", how to attract the customer to innovation; which factors are precisely measured, analysing the expenses to achieve it and the increase in the quantity of buyers (quantitative values). The same way it is possible to define that some of the service qualities are insignificant, therefore, the resources for their creation are spent in vain.

In the process of the research of the factors influencing customer satisfaction, the authors rested upon the following sources: the Rural Tourism Accommodation Quality Evaluation System created by the association Lauku celotājs, the Ishikawa's cause-and-effect diagram, the N. Kano's model, which allows making the logical analysis of the influencing factors, though do not provide the numeric equivalent of the significance value of these factors (Dembovska, Litavniece, \& Silicka, 2017; Kalēja, 2014).

Within the research, an expert-customer ("hidden guest”) questionnaire was developed, and several rural tourism accommodation places were surveyed. The examination of the objects was carried out in the time from June 2017 to September; it was done by two experts, the lecturers of the Faculty of Economics and Management of Rezekne Academy of Technologies (RTA). In the assessment and questionnaire of the quality of services provided by the rural tourism accommodation establishments, 7 factors were included that were divided into 45 sub-factors, for example, an evaluation of the driveway and directional signs to the rural tourism accommodation establishment, buildings and rooms (including furniture), equipment and quality, guest rooms (living-rooms, bathrooms), water supply in the rural tourism accommodation, customer service, catering, and quality, customer information accessibility establishment, customer safety. The assessment data provided by the experts was processed using SPSS.

Overall, the experts examined 61 accommodation places in Rezekne municipality, resting upon the data provided by the TIC of Rezekne municipality. As the result of the research, it was concluded that the classification that is used in the specialised tourism web pages and the positioning of the accommodation places by the accommodation places owners do not correspond considering the services provided. The experts offer their own classification in Table 1. 
Table 1 The examined rural tourism accommodation establishments and their classification in the evaluation of the experts (made by the authors)

\begin{tabular}{|c|c|c|}
\hline $\begin{array}{l}\text { Type of } \\
\text { accommo- } \\
\text { dation }\end{array}$ & $\begin{array}{c}\text { Characteristics of accommodation by } \\
\text { type offered by the experts }\end{array}$ & $\begin{array}{l}\text { Accommodation establishments } \\
\text { satisfying the characteristics in } \\
\text { the experts' comprehension }\end{array}$ \\
\hline $\begin{array}{l}\text { Guest } \\
\text { houses }\end{array}$ & $\begin{array}{l}\text { Recreation rural place in the village or } \\
\text { the suburbs, which is meant for a large } \\
\text { number of visitors. There are no less } \\
\text { than } 3 \text { rooms for overnight stay, sauna, } \\
\text { halls for celebrations or workshops } \\
\text { rooms; various entertainment } \\
\text { opportunities are offered. }\end{array}$ & $\begin{array}{l}\text { Water tourism development centre } \\
\text { Bāka, Ezerkrasti, Vītoli, Rāznas } \\
\text { līcis (Pīlādzis), Rāznas stāvkrasti } \\
\text { (big house), Zal̄ā sala (old } \\
\text { building), Azarkrosti, Balda’s } \\
\text { watermills, Priedītes, Zīdu kolns, } \\
\text { Žubītes, Latgale region } \\
\text { Rehabilitation centre „Razna”, } \\
\text { Birzes, Pērtnieki/ Zaḷā sēta }\end{array}$ \\
\hline $\begin{array}{l}\text { Holiday } \\
\text { cottages }\end{array}$ & $\begin{array}{l}\text { Separate house for guests, often near } \\
\text { bodies of water, a holiday cottage } \\
\text { usually consists of bedrooms, living- } \\
\text { rooms and facilities, although some } \\
\text { exceptions may occur, when there is no } \\
\text { living rooms or facilities are situated } \\
\text { outdoors; prices are indicated for a day } \\
\text { per person or the whole house rent per } \\
\text { day; bedding, tableware and kitchen } \\
\text { equipment is included in the price, } \\
\text { guests are responsible for keeping the } \\
\text { house in order while staying in. }\end{array}$ & $\begin{array}{l}\text { Osmany (2 buildings), Zalāā sala } \\
\text { (new building), Rūmes, Spārītes, } \\
\text { Rāznas līcis, Meirānu krasts (3 } \\
\text { buildings), Zvejnieki (4 buildings), } \\
\text { Veselības Sala ( } 2 \text { buildings), } \\
\text { Azarkrosti, Ezera sonāte, Jān̄i, } \\
\text { Salāji, Skaistā Rāzna, Vilnīši V, } \\
\text { Zeizes, Kazupes, Selena, Burvīgā } \\
\text { Rāzna, Silvija, Peldošā māja, } \\
\text { Rāznas stāvkrasti ( } 2 \text { buildings), } \\
\text { Adamova special boarding school } \\
\text { (separate apartment) }\end{array}$ \\
\hline $\begin{array}{l}\text { Baths with } \\
\text { fishing } \\
\text { facilities }\end{array}$ & $\begin{array}{l}\text { Separate building for baths, where } \\
\text { guests are offered an additional } \\
\text { overnight accommodation }\end{array}$ & $\begin{array}{l}\text { Vēžusala, Austrumi, Dana, Dīḳi (3 } \\
\text { buildings), Kaktiṇi, Kalēji, } \\
\text { Priedītes, Vīteri, Selena, Čiekuri, } \\
\text { Strautiņu mājas, Liepas, Kḷaviņas }\end{array}$ \\
\hline Camping & $\begin{array}{l}\text { Arranged and improved territory for } \\
\text { placement of tents, mobile homes, } \\
\text { trailers, and other lightweight } \\
\text { construction objects, and is meant for } \\
\text { accommodation of visitors. (Vispārīgie } \\
\text { teritorijas plānošanas...) }\end{array}$ & Camping house "Pērtnieki" \\
\hline Hostel & $\begin{array}{l}\text { Private house where the owners have } \\
\text { arranged separate rooms for visitors. } \\
\text { Comfort level is average; breakfast is } \\
\text { served or possibilities for cooking can } \\
\text { be provided as additional service. }\end{array}$ & Albatross, Staroščiki Lejaskalns \\
\hline
\end{tabular}




\begin{tabular}{|l|l|l|}
\hline Tent pitches & $\begin{array}{l}\text { Arranged outdoors territory for tourists } \\
\text { accommodation in the tents; WC and } \\
\text { water supply is provided }\end{array}$ & $\begin{array}{l}\text { Lìdaciņas, Priedītes, leather design } \\
\text { workshop “Apkalnmājas”, } \\
\text { Dzeneiši, Ezermalas, Kauliñi, } \\
\text { horse ranch “Untumi”, Silvija }\end{array}$ \\
\hline $\begin{array}{l}\text { Fishermen's } \\
\text { house }\end{array}$ & $\begin{array}{l}\text { Accommodation is located near the } \\
\text { body of water and offers a low comfort } \\
\text { level overnight accommodation (on } \\
\text { ground, in sleeping bags) under low/ } \\
\text { cold temperature, it is mainly meant for } \\
\text { fishermen, hikers, cycle tourists, } \\
\text { adventurers, and exotic experience } \\
\text { searchers, who enjoy wild nature } \\
\text { activities regularly. }\end{array}$ & Kaleji \\
\hline $\begin{array}{l}\text { Recreation } \\
\text { and sport } \\
\text { camp }\end{array}$ & $\begin{array}{l}\text { Arranged territory for various sport } \\
\text { activities - football, volleyball, } \\
\text { basketball, and other; necessary sport } \\
\text { equipment are provided; } \\
\text { accommodation offer includes separate } \\
\text { rooms, facilities (shower rooms, WC), } \\
\text { rooms or sheds for having food. }\end{array}$ & Jaunais Dinamietis \\
\hline $\begin{array}{l}\text { Hotel in the } \\
\text { rural } \\
\text { territory }\end{array}$ & $\begin{array}{l}\text { Recreation place in the rural area, } \\
\text { village or city with separate rooms for } \\
\text { visitors, with or without breakfast. }\end{array}$ & Zạ̄ā sala (new building) \\
\hline
\end{tabular}

Quality certificates (Kulinārais mantojums, Latviskais mantojums, Quality certificate of Lauku Cel̦otājs, Zalı̄a atslēga certificate, etc.) are publicly visible only in 15 rural tourism accommodation places.

The customer's satisfaction factor "Driveway and directional signs to the rural tourism accommodation establishment" is a factor of the must-be category, as it builds the distribution of communication and information in the environment, and is significant for the accommodation marketing. The biggest problems in the rural tourism accommodation establishments are with directional signs near houses $-47.5 \%$ of accommodation establishments just lack them, or signs are with damages, or their titles do not match the information available on the tourism web portals (8.2\%). Relatively many rural tourism accommodation places (44.3\%) lack directions from the highways, which cause troubles to visitors to find a required rural tourism accommodation place. Inaccurate GPS coordinates (20.6\%) make the situation even worse.

The customer satisfaction factor "Environment" belongs to must-be and reverse category and builds the basic and additional service processes of the rural tourism accommodation establishment. The majority of the Rezekne municipality 
rural tourism accommodation establishments respect this factor (a well-kept territory, mown lawns, the territory is not littered, a car can be parked near the accommodation place).

The assessment of the customer satisfaction factor "Quality of buildings and rooms" shows that in $63.63 \%$ cases the experts give a positive evaluation to the sub-factor "Buildings and their parts are in functional order", but in $36.37 \%$ cases, the buildings and their parts just partially are or are not in functional order (for example, peeling paint on the front and window frames of the building, the staircase is not in functional order, the customer is not informed about the ongoing maintenance therefore it is not possible to stay in). The sub-factors "Rooms are clean - there is no dust and dirt on the furniture", "Windows are clean", "Rooms are not littered, there is no rubbish inside", "Rooms are ventilated, there is no smell in them" match the must-be factor category and is important and should be valued in the guest service circle. The results of the examination show that the biggest threat comes from the sub-factor "Windows are clean", as it was found that $74.54 \%$ of hosts do not observe or just partly observe this factor. In $63.36 \%$ of the cases, the sub-factor "Rooms are clean - there is no dust and dirt on the furniture" is in absolute order. However, the authors believe that the comparatively high unsatisfactory value of this factor is a serious threat to the impression of the general rural tourism accommodation services quality in the examined territory.

The sub-factors "Shared rooms' correspondence to the quantity of guests, accommodation size, style, number and location of rooms", "One can easily move around the furniture in the room", "Rooms are warm", "Facilities correspond to the number of guests", "Accessibility and facilities for people with movement disorders", "There is a separate smoking area", "Internet access" depend on the subjective perception of guests and comprise must-be, qualitative, and reverse categories.

As the majority of the rural tourism accommodation places in Rezekne municipality are positioned as places for event/ parties' arrangements, it means that the sub-factor "Correspondence of shared space to the quantity of guests, accommodation size, style, number and location of rooms" apply. However, it does not provide the necessary level of comfort for individual tourists (1 or 2 persons) (for example, a double room has 3 beds; there are bedrooms only for 5 and 10 persons). Thereby, the sub-factor "One can easily move around the furniture in the room" is hard to accomplish. In $90.9 \%$ of the cases, the experts evaluated the sub-factor "Rooms are warm" in a confirmative way, however, they admit the result might be different during the heating season (cold weather). The sub-factor "Facilities correspond to the number of guests" in $82.0 \%$ of the cases is appropriate, however, it should be emphasised that the level of morally outdated facilities is comparatively high. The sub-factor "Accessibility and facilities for 
people with movement disorders" in $73.21 \%$ of the cases is not observed or is observed just partly (12.5\%). As per the experts', it is connected with the time when the rural tourism accommodation places were built, because the new objects are adjusted for people with movement disorders. The sub-factor "Internet access" mostly is not met or is met just partly. The experts believe Wi-Fi access is essential for a modern tourist.

The customer satisfaction factor "Guest rooms (living-rooms, bathrooms) evaluation" is must-be, qualitative, and reverse and determines the tourist repeated choice of the object. The sub-factor "Quality of beds: steady, does not creak, bend or crumple, the base, foot side and head side are without damages; the mattress is clean, without spots or smells, it is smooth and comfortable for sleeping”. This criteria is appropriate only in $23 \%$ of Rezekne municipality rural tourism accommodation establishments (it should be taken into account that the experts were not able to test this sub-factor in every object). In general, the experts conclude, the quality of beds provides the low level of comfort and visual evaluation. The sub-factors "The size of a single bed corresponds to the 90/190 standard" and "The size of a double bed corresponds to the 150/190 standard" was mostly evaluated by the experts as average since the width of a single bed is within the range of $80-85 \mathrm{~cm}$. Folding couches are offered in all bathhouses with accommodation services, it is difficult to value them as double beds, since two beds are joined together and the joint place feels inconvenient. The sub-factors "Bedside table or shelf for every guest" and "One chair for every guest" was mostly evaluated by the experts as average, as only one shelf and one chair was provided in a double room. The sub-factor "Place to hang on or put in clothes for every guest" mostly is observed, as there are closets in the rooms and hangers are placed on the walls. The sub-factors "Floor area with the shower is at least $3 \mathrm{~m}^{2}$ " and "Shower curtain or shower cabin, non-sliding surface in the shower cabin or a rug, shelf or locker, door with a lock, toilet paper, wall socket" and "There is a sink in the bathroom, and there is a mirror above it" were evaluated as average in many objects, as the access to the shower was difficult; there was no wall socket, mirror, shelves in bathroom, and the floor area was less than $3 \mathrm{~m}^{2}$ as well. The sub-factor "Beddings are not worn out" mostly is evaluated as average, as the beddings are clean, not torn, but morally out of date (washed-out colours, different sets combined together, etc.).

The factor "Water supply" is satisfied in more than $70 \%$ of the cases, as there is access to hot water, without breaks in supply and with no smell. The experts were not able to test water supply in $3.3 \%$ of the cases; as the result, "no information" response was provided.

The experts value the factor "Customer service, communication" as satisfied, and stress that Rezekne municipality rural tourism accommodation owners or staff welcome customers, provide them with necessary information (being asked or on 
their own). The experts evaluate customer service as one of basic factors of customer satisfaction. The experts see the issue in communication that was visible in particular rural tourism accommodation places, for example, the lack of language knowledge or etiquette knowledge, forgetting that the customer has booked a room, coming to the arranged meeting in work clothes, unwillingness to show the rooms to a particular guest, offering to see them in the Internet instead.

An assessment of the customer's satisfaction factor "Catering" reflects a significant problem in the tourism product offer in general. The sub-factor "Offer includes breakfast" demonstrates, in according to the experts' opinion, an essential problem - availability of catering services in Rezekne district. That suggests that owners of rural tourism accommodation establishments are not ready to offer such a service. The problem is caused by the fact that $32.8 \%$ of the guests also have no opportunity to cook their breakfast themselves. In $65.6 \%$ of the cases, the subfactor "Possibility to cook" is offered. However, the sub-factors "Available equipment (pans, kettles, fridge, etc.)", "Number of dishes corresponds to number of customers (glasses, plates, forks, etc.)" and "Similarity of tableware is observed" are just partially met, since the tableware are worn out, are of different style and creates a chaotic impression.

The factor "Additional Services" affecting customers' satisfaction is important as it can contribute to a tourist's choice. Mostly rural tourism accommodation establishments that are located near water bodies offer fishing opportunities, boat rides, and sports activities. However, all the auxiliary services offered are alike, which testifies about lack of variety of active tourism products in Rezekne municipality. $73.8 \%$ of the observed accommodation establishments have beaches, but they are not always available to all tourists because the stairs do not have rails, wooden planks are unstable, dirty boats and catamarans are offered. Bathhouse services are offered at guesthouses and holiday houses at additional cost.

The sub-factors of the category "Information" affecting the customer's satisfaction as "Tourism information about surroundings, services and leisure facilities (booklets, maps)" and "Printed materials about rural tourism accommodation establishment, including materials in the room (menu, rules, information on auxiliary services)" are not observed respectively in $57.4 \%$ and $73.8 \%$ of the cases. Information on the services is provided verbally, there is a lack of information at the site about services and prices offered.

The "Safety" factor is not met (27.9\%) or met partially (13.1\%), for example, there are no instructions about fireplace and stove heating, bathhouse usage rules, and, in some cases, the experts did not have access to view all the premises and available information. 


\section{Conclusions}

The assessment of the quality of a rural tourism accommodation shall be based on the following quality indicators:

1. Demand for the rural tourism accommodation (for example, number of visitors, number of overnight stays, length of stay, etc.).

2. Perception of the rural tourism accommodation type, comfort level, associations of comfort level, satisfaction, etc.

These indicators can be used to analyse value customers' perceived quality.

In result of the research, it was found that a large part of the rural tourism accommodation providers incorrectly indicate classification of the rural tourism accommodation establishments, for example, at the website www.booking.com the accommodation is positioned as a guesthouse, but information at Rezekne municipality's website differs misleading the customer. The owners of rural accommodation services have to review type of accommodation indicated at all places the public information is provided (booking sites, website, the Rezekne municipality website, booklets, maps, etc.).

The existing information on the rural tourism accommodation establishments - type of accommodation, services offered, prices, GPS coordinates - varies in different sources of information (Rezekne Municipality website, homepages of rural tourism accommodation establishments, at the website www.booking.com).

The locations of the tourist accommodation establishments in the territory of Rezekne municipality are unevenly distributed (concentrated mainly by the Razna Lake and the Lubana Lake, and Rezekne neighbourhoods).

The overall assessment of the "perceived quality" of the rural tourism accommodation services in Rezekne municipality affects the customer's satisfaction as depreciation of buildings, furniture, inventory is visible. However, this conclusion does not relate to particular rural tourism accommodation establishments, but is connected to the offer in general. These are "tangible" (according to N. Kano - technical) factors, but "not-tangible" (according to $\mathrm{N}$. Kano - human) factors in Rezekne municipality rural tourism housings in general can be characterized by the keywords "responsiveness" and "hospitality".

In rural tourism places, the factor of cleanliness, which is "tangible" (according to N. Kano - technical) factor, is essential, though, it is an integral part of the "non-tangible" (according to N. Kano - human) factor. Thus, for example, dirty windows, spider nets outside the house in a rural tourism accommodation create a general negative impression of the offer.

The owners of rural tourism accommodation establishments should assess both current and the future demand, define precisely the potential market segment and build an offer accordingly. For example, if the main offer of a tourist 
accommodation is sauna services with accommodation possibility, it should be positioned in that way. In addition, it is necessary to find the special INDIVIDUAL value of the accommodation house and link it with the customer's perception.

In Rezekne municipality, there are valuable and diverse natural and cultural resources that are not used to full extent, though they have potential to be used for development of a specialized, recreational, cognitive tourism product.

Future development of rural tourism accommodation establishments will be determined by several factors influencing development:

- Distance to the magnetic object. In accordance with the researchers, there are 3 magnetic objects in Rezekne municipality - the Luznava Manor, the Razna Lake, and the Lubana Lake. As well, there is a possibility to develop rural tourism lodgings of different quality in the immediate vicinity of Rezekne city, taking into account the magnetic objects in Rezekne and the offer of the existing accommodation services in Rezekne (Dembovska, Litavniece, \& Silicka, 2017).

- $\quad$ Distance to the main public roads.

- $\quad$ The overall image of Rezekne municipality. The image is composed of the hospitality enterprises (including quality of service, existence and quality of catering services, auxiliary services and their quality and diversity, etc.) and infrastructure (getting to the rural tourism accommodation establishment from the main roads, accuracy of GPS coordinates, availability of the Internet, etc.)

- Evaluation of hospitality enterprises. According to the project researchers, the quality assessment of the rural tourism accommodation establishment should be a continuous process, the basic principles of which should be in line with the DEMING Cycle (PLAN - DO CHECK - ACT), thus, at any moment the Tourist Information Centre can be sure of the quality of rural tourism accommodation services in the area.

- $\quad$ Ability to create new and innovative products essentially based on the experience economy.

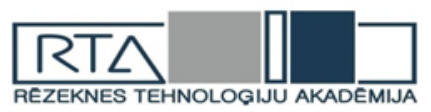

The paper was produced with the financial support of Rezekne Academy of Technologies from the research grant "Tourism Products Evaluation of the Rezekne Municipality

(Quality Audit)”. 


\section{References}

Daugeliene, R. (2006). Towards a Knowledge - based Economy: Modelling Knowledge Expression Assessment. European Union Enlargement of 2004 and Beyond: Responding to the Political, legal and Socio- Economic Challenges. University of Latvia.

Dembovska, I., Litavniece, L., \& Silicka, I. (2017). Assessment of spa hotel services' development opportunities in Rezekne city. Proceedings of the 18th annual International Scientific Conference "Economic Science for rural development". April 27-28, 2017. Jelvgava, LLU, 201-212

Dembovska, I., \& Silicka, I. (2014). Lauku tūrisma ilgtspējīga attīstība Latgalē. Latgales tautsaimniecības pētījumi. Sociālo zinātņu žurnāls. Nr. 1 (6). Rezekne: RA Izdevniecība. Retrieved from file:///C:/Users/User/Downloads/1166-1977-1-PB\%20(2).pdf

Ishikawa, K. (1990). Introduction to Quality Control. 3A Corporation, Tokyo.

Kalēja, E. (2014). Kvalitāte lauku tūrismā kā veicinošs faktors produktu un galamērķu attīstībā. Zemgales tūrisma konferences materiāli 2014.g.3.decembris. Retrieved from http://www.bauskata.lv/userfiles/Lauku_celotajs_ZTA_konference.pdf

Kano, N. (1996). Guide to TQM in Service Industries. Asian Productivity Organization, Tokyo.

Latvijas investīciju un attīstības aǵentūra. Türisms. Retrieved from http://www.liaa.gov.lv/ lv/turisms

Lauku Tūrisma mītņu kvalitātes vērtēšanas sistēmas lietotāju rokasgrāmata (2006). Retrieved from https://www.celotajs.lv/cont/prof/proj/doc/Rokasgramata_1.doc

Muška, A. (2003). Tūrisma produkts un tā kvalitāte Latvijas regionos. Promocijas darba kopsavilkums. Retrieved from http://lufb.llu.lv/dissertation-summary/tourism/kopsavAina-Muska.pdf

Naktsmìtnes lauku un reǵionālajā tūrismā. Retrieved from http://aurora.turiba.lv/ training/LV/Accommodation_LV/Module.pdf

Pike, S. (2008). Destination Marketing. An Integrated Marketing Communication Approach (pp. 350 - 369). Oxford: Butterworth - Heinemann.

Steina van der, A. (2012). Latvijas kā tūrisma vietas mārketinga darbības efektivitāte. Promocijas darba kopsavilkums. Retrieved from https://dspace.lu.lv/dspace/ bitstream/handle/7/5195/33442-Aija_Van_der_Steina_2012.pdf?sequence=1

Vispārīgie teritorijas plānošanas, izmantošanas un apbūves noteikumi MK240. Retrieved from https://likumi.lv/doc.php?id=256866 